\title{
ДЕТЕРМІНАНТИ, ЩО ВПЛИВАЮТЬ НА ВЧИНЕННЯ НЕПОВНОЛІТНІМИ КРИМІНАЛЬНИХ ПРАВОПОРУШЕНЬ ПРОТИ ВЛАСНОСТІ
}

\author{
ЯКОВЛЕВА Тетяна Костянтинівна - ад'юнкт кафедри кримінального \\ права та кримінології (Донецький державний університет внутрішніх справ, \\ м. Маріуполь) \\ УДК:343.132.1 \\ 10.32782/EP.2021.4.20
}

Досліджуються проблеми детермінацй злочинності. Аналізуються детермінанти, що впливають на вчинення неповнолітніми кримінальних правопорушень проти власності. Визначаються та розглядаються групи таких детермінант, як: соціально-економічні, суспільно-політичні, правові, сочіальнопсихологічні, організачійно-управлінсъкі та детермінанти, пов'язані з недоліками правоохоронної $i$ правозастосовної діяльності. Обгрунтовується висновок, що запровадження та реалізачія підрозділами Національної поліциї Украйни разом з органами державної влади та місиевого самоврядування спільних безпекових програм та проєктів значно сприяе зниженню рівня злочинності неповнолітніх.

Ключові слова: детермінація, злочинність неповнолітніх, злочини проти власності, пробілактика дитячої злочинності.

\section{Постановка проблеми}

Одним із головних напрямків дослідження проблем злочинності $\epsilon$ вивчення iї детермінації. Визначення детермінантів, що впливають на вчинення злочинів, надає змогу вживати заходів щодо їх усунення або мінімізації їхнього негативного впливу.

Дослідження проблем злочинності неповнолітніх завжди були і залишаються актуальними у суспільстві та державі. Водночас, проблема детермінації кримінальних правопорушень проти власності, що вчиняються неповнолітніми, детально не досліджувалася. Зокрема, має свою специфіку детерміна- ція таких злочинів, скоєних підлітками, які мешкають на лінії розмежування з тимчасово окупованою територією Донецької області. Тому вважаємо за необхідне розглянути теоретичні та прикладні аспекти детермінації такої злочинної поведінки в наведених умовах.

\section{Аналіз останніх досліджень і публікацій}

Проблема детермінації злочинності привертала увагу багатьох учених, юристів, соціологів, психологів. Над ії дослідженням працювали О. М. Бандурка, А. Ф. Волобуєв, А. М. Давиденко, І. М. Даньшин, О. М. Джужа, А. П. Закалюк, В. С. Зеленецький, А. Ф. Зелінський, О. Г. Кальман, О. М. Костенко, В. М. Кудрявцев, Н. Ф. Кузнєцова, Н. Н. Ярмиш та інші.

Метою цієї статті є вивчення детермінантів, що впливають на вчинення неповнолітніми злочинів проти власності та визначення напрямків профілактичної діяльності органів державної влади та інститутів громадянського суспільства, які сприятимуть досягненню бажаного рівня кримінологічної безпеки.

Виклад основного матеріалу

На початку слід зазначити, що злочини проти власності є однією з найпоширеніших і найнебезпечніших груп злочинних діянь, оскільки вони посягають на одне 3 
найцінніших соціальних благ - право власності. Захист права власності має особливе суспільне значення, що передбачене ст. 13 Конституції України, яка проголошує рівність усіх суб'єктів права власності перед законом і забезпечення захисту їх прав державою. Відповідно до ст. 41 Основного Закону, ніхто не може бути протиправно позбавлений права власності; право власності є непорушним [1].

Особливе занепокоєння викликають ті випадки, коли злочини проти власності скоюються особами, у яких на достатньому рівні ще не сформована система цінностей, а саме неповнолітніми.

У Кримінальному кодексі України (далі - КК України) відповідальність за злочини проти власності закріплено у розділі VI «Злочини проти власності». 3 огляду на специфічні ознаки суб' єкту злочину, що розглядається, ми дослідили кримінальні правопорушення, передбачені статтями 185-191 КК України, скоєні особами у віці від 14 до 18 років.

Так, на території Донецької області від початку проведення Антитерористичної операції (квітень 2014 року) неповнолітніми скоєно 2125 злочинів проти власності, зокрема: у 2014 році - 272, 2015 381,2016 - 363, 2017 - 283, 2018 - 336, 2019 - 313 та у 2020 році - 177 кримінальних правопорушень. Наведені дані свідчать про зростання майнової злочинності серед неповнолітніх саме після початку бойових дій на Сході України, які детермінували низку соціальних, економічних, політичних та правових явищ (велика кількість постраждалих осіб, внутрішне переміщення мешканців окупованих територій, руйнування інфраструктури регіону, безробіття тощо).

У науці під детермінацією розуміють форму спрямованого зв'язку, коли один об'єкт визначає інший, можливо, ще не обумовлює і тим більше не спричинює його, але між ними є детерміністична залежність. Детермінізм означає зв'язок, що виявляється у залежності речей (властивостей речей і відносин між ними, подій, процесів, станів) у їх існуванні та зміні від будь-яких факторів [2, c. 30].
У структурі детермінації злочинів визначають дві групи обставин, а саме: формування особистості (антисуспільна установка) та зовнішній матеріальний світ (конкретна життєва ситуація), який впливає на особу в процесі вибору нею злочинної поведінки. Звісно, такі обставини безпосередньо не спричиняють вчинення злочину, їх слід розглядати лише як умови (детермінанти) скоєння конкретних правопорушень.

Також для розуміння суті детермінації злочинів дуже слушним є твердження про те, що в соціальних явищах детермінація не може бути неминучістю у вигляді лінійної залежності, оскільки завжди має ймовірний характер [3, с. 107].

Практика свідчить, що у більшості кримінальних проваджень вагомою причиною антигромадської поведінки неповнолітніх виступає саме несприятливе формування особистості, рідше - порівняно випадкові приводи. Так, із загальної кількості неповнолітніх (2099), якими було скоєно кримінальні правопорушення на території Донецької області у період з 2014 до 2020 року - 511 або 24,3\% скоєно особами, які ніде не навчаються, 3 яких 280 або 54,8 \% - у нетверезому стані. І це лише офіційна статистика.

Таким чином, з урахуванням аналізу сучасних визначень, понять, причин i умов кримінальних правопорушень проти власності, що вчиняються неповнолітніми, вважаємо, що причиною таких злочинів є сформована під впливом різних негативних явищ і процесів антисуспільна установка в свідомості особи, яка спричинила в неї рішучість вчинити злочин або призвела до вчинення злочину.

Формою всіх кримінальних правопорушень є дія або бездіяльність особи, що завдала шкоди об'єкту (об'єктам) кримінально-правової охорони, і низка об'єктивних та суб'єктивних чинників, які були його умовами. Жодна з цих умов і навіть всі вони разом узяті самі по собі безпосередньо не породжують злочин (тобто не спричиняють кримінально караної шкоди), а тільки зумовлюють його, а відтак визначають його характер.

Отже, залежно від сфери виникнення й функціонування можна визначити групи де- 


\section{Кримінальне право, кримінальний процес та криміналістика}

термінант злочинів, які впливають на вчинення неповнолітніми кримінальних правопорушень проти власності, а саме: соціально-економічні, суспільно-політичні, правові, соціально-психологічні, організаційноуправлінські та детермінанти, пов'язані 3 недоліками правоохоронної і правозастосовної діяльності. Розглянемо найбільш значущі $з$ них.

Так, до економічних чинників, що детермінують скоєння неповнолітніми майнових злочинів слід віднести: об'єктивне протиріччя між економічними потребами особи i можливостями батьків (опікунів) та суспільства в їх задоволенні, наявність високого рівня безробіття в регіоні, зниження рівня життя значної частини населення. 3 огляду на це, суб'єктів нашого дослідження умовно можна поділити на матеріально забезпечених та недостатньо забезпечених. Такий розподіл, насамперед, пояснюється особливостями доходів (витрат) та недотриманням принципів справедливості в суспільстві.

3 початку становлення незалежності в Україні існує безліч об'єктивних факторів, що формують високий рівень злочинності, зокрема: значне розшарування суспільства за рівнем матеріальної забезпеченості, обсягу й якості доступних соціальних послуг, занепад звичних людських життєвих орієнтирів та ідеологічних цінностей, послаблення внаслідок цього родинних, сімейних, ділових та інших зв'язків, поступове зростання агресіï.

В. Н. Кудрявцев та В. Е. Емінов вважають, що причини злочинності необхідно передусім шукати в економічних стосунках, їх протиріччях, незбалансованості господарського механізму, вадах і недоліках економічної політики, а також у системі розподільних стосунків [4, с. 61].

Одним із об'єктивних чинників, причинно пов'язаних із майновою злочинністю, 6 неналежні побутові умови. Вік суб'єктів нашого дослідження (14-18 років) свідчить, що в цей період свого життя неповнолітні особи навчаються у закладах середньої або вищої освіти, а отже, необхідні кошти на навчання та потреби отримують від батьків (опікунів). При цьому більша частина учнів і студентів, переведених із навчальних закладів Доне- цької і Ауганської областей, залишаються малозабезпеченими через втрату батьками роботи та постійного місця проживання.

Майже $40 \%$ дітей, які скоїли злочин, мешкають у сім'ях зі складними життєвими обставинами. За суттєвого економічного розшарування значна частина підлітків не в змозі задовольнити не лише завищені, а й нормальні потреби матеріального характеру. Невдоволеність рівнем свого життя, неспроможність поліпшити своє матеріальне становище призводять до збільшення кількості конфліктних ситуацій і внаслідок - до вчинення насильницьких та майнових злочинів.

Також слід зазначити, що злочинність неповнолітніх часто має тісний зв'язок з такими негативними явищами, як алкогольна чи наркотична залежність, оскільки такі злочини, як крадіжки, грабежі, розбійні напади та вимагання, зазвичай скоюються під впливом алкоголю або наркотичних (психотропних) речовин.

Причиною конкретного злочину є результат взаємодії негативних особистісних чинників, що виникли під впливом несприятливих умов морального формування особистості і зовнішніх криміногенних обставин [5, с. 62]. Слід зауважити, що в кримінології чимало вчених присвятили свої дослідження визначенню єдиної «універсальної» причини злочинності. Деякі науковці вважають загальною причиною злочинності у будь-якому суспільстві - об'єктивні соціальні протиріччя [6, с. 76].

Зокрема, в ідеологічній, духовній сферах життя суспільства простежується втрата значною частиною населення загальновизнаних людських ідеалів, правовий нігілізм, «криміналізація» значної частини населення, недостатня довіра до правоохоронних органів та ін. При цьому не можна залишити поза увагою деструктивний вплив на морально-етичний світ людини, насамперед на психологічно й культурно несформовану молодь, який здійснюють засоби масової інформації та соціальні мережі Інтернет. Йдеться про надмірну романтизацію та героїзацію образу осіб, які вчиняють злочини як насильницької, так і майнової спрямованості. 
Так, М. О. Семенишин обгрунтовує необхідність розробки концепції виховання дітей у суспільстві, оскільки соціальна нестабільність і ціннісно-нормативна криза у Донецькій та Ауганській областях, а також воєнні дії значною мірою деформують сприятливе середовище для морального виховання молоді $[7$, с. 270].

До організаційно-управлінських чинників, що впливають на вчинення неповнолітніми кримінальних правопорушень проти власності, можна віднести відсутність дієвої законодавчої бази боротьби з дитячою злочинністю, коли криміногенна ситуація змінюється швидше, ніж чинне законодавство, а також організаційно-тактичні прорахунки під час організації та здійснення боротьби з майновою злочинністю.

Детермінантами, пов'язаними 3 недоліками правоохоронної і правозастосовної діяльності, є:

- зниження ефективності або взагалі відсутність превентивних та оперативних заходів підрозділів Національної поліції України;

- прорахунки у кадровому забезпеченні та плинність начальницького складу підрозділів поліції і, як наслідок, втрата професійно підготовлених працівників, практичного досвіду в організації оперативної та превентивної діяльності, що, у свою чергу, призводить до відсутності належного обліку осіб, які становлять оперативний інтерес, незадовільної організації взаємодії підрозділів ювенальної превенції, оперативних підрозділів зі слідчими, іншими правоохоронними органами та громадськістю;

- неврахування особливостей регіональних умов, відсутність або низький рівень контролю за способом життя осіб, які перебувають на обліку, відсутність наступальності у боротьбі з майновою злочинністю неповнолітніх тощо.

Встановлення конкретних причин тривалого вчинення злочинів неповнолітніми має надважливе значення для підвищення результативності боротьби з таким явищем. Відтак, на думку Г. А. Аванесова, у причинах та умовах конкретних злочинів потрібно виявляти те, що є загальним для всіх злочинів $[8$, c. 200].
Отже, дослідження детермінантів, які впливають на вчинення неповнолітніми майнових злочинів, дає змогу визначити заходи щодо їх запобігання.

Ураховуючи те, що злочинність неповнолітніх може слугувати базисом для розвитку рецидивної та професійної злочинності, Головним управлінням Національної поліції в Донецькій області визнано одним із пріоритетних напрямків діяльності саме профілактику дитячої злочинності. Так, у 2019 році ГУНП в Донецькій області разом з відповідними службами Донецької облдержадміністрації було розроблено та запроваджено Регіональну програму профілактики правопорушень серед дітей на території Донецької області на 2019-2022 роки [9], заходи якої спрямовані на зниження рівня правопорушень серед дітей, реалізацію та захист їх прав і свобод, удосконалення морального, патріотичного виховання та підвищення правосвідомості. Під час реалізації заходів Програми запроваджено низку безпекових проєктів, зокрема: «Відновні практики: прості рішення складних питань», Інформаційний простір «Дитячий коп», «Діти+поліція=безпека та мир», «Простір миру та безпеки» та інші [10].

У 2020 році поліцейськими разом з фахівцями Донецького державного університету внутрішніх справ розроблено Концепцію забезпечення кримінологічної безпеки на території Донецької та Ауганської областей до 2025 року, сутність якої полягає у захисті прав і свобод кожної людини та розв'язання проблем забезпечення національної безпеки у регіонах [7, с. 359].

Окремим форматом запобігання злочинності серед молоді на Донеччині $є$ взаємодія поліції з громадською організацією Молодіжна Ліга майбутніх поліцейських» [11], яка складається 3 дітей-патріотів із населених пунктів на лінії розмежування. Діяльність Аіги дозволяє активній та талановитій молоді, яка прагне якісних змін, долучитися до становлення нової поліції та допомагає у правовому та національно-патріотичному вихованні дітей та молоді.

Про ефективність та результативність заходів, що проводяться в межах наведених програм та безпекових проєктів свідчать по- 


\section{Кримінальне право, кримінальний процес та криміналістика}

точні статистичні дані. Так, протягом 2020 року неповнолітніми на території Донецької області було скоєно 177 майнових злочинів, проти 313 у 2019 році.

\section{Висновок}

Таким чином, запобігання майновій злочинності неповнолітніх, з одного боку, вимагає від науковців і правників більш глибокого вивчення детермінантів, що впливають на вчинення таких злочинів 3 подальшою розробкою комплексу профілактичних заходів та їх прийнятті на державному рівні. А з іншого - запровадження і реалізації підрозділами Національної поліції України разом із органами державної влади та місцевого самоврядування відповідних безпекових проєктів, які сприятимуть подальшій реалізації механізмів прав та свобод людини та досягненню бажаного рівня кримінологічної безпеки.

\section{Аітература}

1. Конституція України: Закон від 28 черв. 1996 р. № 254к/96-ВР. Верховна Рада України. URL: https://zakon. rada.gov.ua/laws/main/254\%D0\% $\quad$ BA/96\%D0\%B2\%D1\%80\#Text.

2. Аскин Я. Ф. Философский детерминизм и научное знание. М.: Мысль, 1977. $188 \mathrm{c}$.

3. Кальман О. Г. Стан і головні напрямки запобігання економічної злочинності в Україні: теоретичні та прикладні проблеми: монографія. Х.: Гімназія, 2003. 352 с.

4. Криминология: учебник / под ред. акад. В. Н. Кудрявцева, проф. В. Е. Эминова. М.: Юрист, 1995. 512 с.

5. Кримінологія: навч.-метод. посіб. / за заг. ред. О. М. Джужи, С. М. Моїсєєва,В. В. Василевич та ін. К.: Атіка, 2003. 400 с.

6. Кримінологія: навч. посіб. / О. М. Джужа, В. В. Василевич, О. Г. Колб та ін.; за заг. ред. д-ра юрид. наук, проф. О. М. Джужи. К.: Атіка, 2009. 312 с.

7. Семенишин М. О. Концептуальні засади запобігання корисливо-насильницьким злочинам органами та підрозділами національної поліції України (за матеріалами операції Об'єднаних сил): монографія. Київ: ВД «Дакор», 2020. 550 с.
8. Криминология: учебник. 3-е изд., перераб. и доп. / под ред. Г. А. Аванесова. М.: Юрид. лит., 2005. 455 с.

9. Регіональна програма профілактики правопорушень серед дітей на території Донецької області на 2019 - 2022 роки: розпорядження Голови ОДА від 23.11.2018 № 1410/5-18. Офіційний сайт Донецької обласної державної адміністраціï. URL: https://dn.gov.ua/storage/app/sites/1/ publicinfo/1410-18.pdf.

10. Проєкти. Офіційний сайт ГУНП в Донецькій області. URL: https://dn.npu.gov. ua/activity/ekspertna-rada-innovaczijnix-idej/ proekti.html

11. Про Аігу. Офіційний сайт громадської організації. URL: http://liga-police.com. ua/about.

\section{References}

1. Konstytutsiia Ukrainy: Zakon vid 28 cherv. 1996 r. № 254k/96-VR. Verkhovna Rada Ukrainy. [Constitution of Ukraine: Law of June 28. 1996 № 254k 96-BP. Verkhovna Rada of Ukraine]. URL: https://zakon. rada.gov.ua/laws/main/254\%D0\% BA/96$\% \mathrm{D} 0 \% \mathrm{~B} 2 \% \mathrm{D} 1 \% 80$ \# Text. [in Ukrainian].

2. Askin YA. F. Filosofskij determinizm i nauchnoe znanie. [Philosophical determinism and scientific knowledge]. M.: Mysl', 1977. 188 s. [in Russian].

3. Kalman O. H. Stan i holovni napriamky zapobihannia ekonomichnoi zlochynnosti v Ukraini: teoretychni ta prykladni problemy: monohrafiia. [Status and main directions of economic crime prevention in Ukraine: theoretical and applied problems: monograph]. X.: Himnaziia, 2003. 352 s. [in Ukrainian].

4. Kriminologiya: uchebnik pod red. akad. V. N. Kudryavceva, prof. V. E. Eminova. [Criminology: textbook]. M.: YUrist, 1995. 512 s. [in Russian].

5. Kryminolohiia: navch.-metod. posib. za zah. red. O. M. Dzhuzhy, Ye. M. Moisieieva, V. V. Vasylevych ta in. [Criminology: teaching method. way.]. K.: Atika, 2003. 400 s. [in Ukrainian].

6. Kryminolohiia: navch. posib. O. M. Dzhuzha, V. V. Vasylevych, O. H. Kolb ta in.; za zah. red. d-ra yuryd. nauk, prof. O. M. Dzhuzhy. [Criminology: textbook. way.]. K.: Atika, 2009. 312 s. [in Ukrainian]. 
7. Semenyshyn M. O. Kontseptualni zasady zapobihannia koryslyvo-nasylnytskym zlochynam orhanamy ta pidrozdilamy natsionalnoi politsii Ukrainy (za materialamy operatsii Obiednanykh syl): monohrafiia. [Conceptual principles of prevention of mercenary and violent crimes by bodies and subdivisions of the National Police of Ukraine (based on the materials of the Joint Forces operation)]. Kyiv: VD «Dakor», 2020.550 s. [in Ukrainian].

8. Kriminologiya: uchebnik. 3-e izd., pererab. i dop. / pod red. G. A. Avanesova. [Criminology]. M.: YUrid. lit., 2005. 455 s. [in Russian].

9. Rehionalna prohrama profilaktyky pravoporushen sered diteina terytorii Donetskoi oblasti na 2019 - 2022 roky: rozporiadzhennia Holovy ODA vid 23.11.2018 № 1410/5-18. Ofitsiinyi sait Donetskoi oblasnoi derzhavnoi administratsii. [Regional program of crime prevention among children in the Donetsk region for 2019 - 2022]. URL: https://dn.gov. ua/storage/app/sites/1/publicinfo/1410-18.pdf. [in Ukrainian].

10. Proiekty. Ofitsiinyi sait HUNP v Donetskii oblasti. [Projects. Official site of GUNP in Donetsk region.]. URL: https://dn.npu.gov. ua/activity/ekspertna-rada-innovaczijnix-idej/ proekti.html. [in Ukrainian].

11. Pro Lihu. Ofitsiinyi sait hromadskoi orhanizatsii. [About the League. Official site of the public organization]. URL: http://ligapolice.com.ua/about. [in Ukrainian].

\section{DETERMINANTS AFFECTING THE COMMISSION OF CRIMINAL OFFENSES BY MINORS AGAINST PROPERTY}

The article examines the problem of determination of juvenile delinquency. Analyzed are the determinants affecting the commission of criminal offenses by minors against property in the area of the anti-terrorist operation (operation of the combined forces), in particular on the line of demarcation with the temporarily occupied territory of the Donetsk region.
The groups of such determinants of juvenile delinquency as: socio-economic, socio-political, legal, socio-psychological, organizational and managerial and determinants associated with the shortcomings of law enforcement and law enforcement are considered. It is determined that the reason for the commission of such crimes is the antisocial attitude formed under the influence of various negative phenomena and processes in the consciousness of the individual, which caused her determination to commit a crime or led to the commission of a crime.

It is noted that since the beginning of the anti-terrorist operation in the territory of Donetsk region, minors have committed 2,125 crimes against property. At the same time, the number of these crimes was growing until 2019. Considering that juvenile delinquency can serve as a basis for the development of recidivist and professional crime, the police of the Donetsk region recognized prevention of juvenile delinquency as one of the priority areas of its activity and adopted a set of preventive measures provided for by the relevant strategies, concepts, regional program for the prevention of juvenile delinquency, as well as security projects. The implementation of such preventive measures helped to reduce the commission of crimes by minors in 2019 and 2020.

Thus, a thorough study of the determinants affecting the commission of property crimes by minors, in certain conditions (situation), makes it possible to determine a set of necessary measures to prevent them.

In the end, the conclusion is substantiated that the introduction and implementation of joint security programs and projects by the units of the National Police of Ukraine, jointly with state and local authorities, significantly contributes to the reduction of the level of juvenile delinquency.

Keywords: determination, juvenile delinquency, crimes against property, prevention of juvenile delinquency. 